Mariusz Tabulski OSPPE

\title{
Maryja Matką Kościoła. Inspiracje formacji maryjnej w pismach prymasa Wyszyńskiego i na podstawie nauczania Magisterium Kościoła
}

\section{Wstęp}

Najświętsza Maryja Panna jako Matka Kościoła doznawała czci już od początków istnienia chrześcijaństwa. W swoich rozważaniach czynili to najpierw ojcowie Kościoła, następnie teologowie wieków późniejszych, a w ostatnich czasach papieże: Leon XIII, Jan XXIII, Paweł VI i Jan Paweł II. Dzieje maryjnego kultu Kościoła w Polsce, jego śluby i oddanie Królowej Polski z Jasnej Góry było momentem szczególnym w doświadczeniu kryzysu powojennego XX wieku i odnowienia Kościoła, jakie przyniósł II Sobór Watykański. Wielokrotnie dawał temu wyraz Episkopat Polski na czele z prymasem Stefanem Wyszyńskim. Sam kard. Wyszyński znalazł dla siebie i dla udręczonego Kościoła w Polsce ratunek w Jasnogórskiej Matce. Już w czasie Soboru wygłosił płomienne przemówienie, w którym podkreślał, że tak bardzo dręczona i zagrożona w swej egzystencji ludzkość potrzebuje Matki. Powoływał się na doświadczenia polskiego narodu, dla którego Matka Chrystusa w jego dziejach była ratunkiem, pomocą i zwycięstwem. Należy również podkreślić, że ojcowie soborowi z Polski 
usilnie zabiegali o to, aby nauka o roli i misji Najświętszej Maryi Panny została włączona do Konstytucji dogmatycznej o Kościele, dlatego że „to podkreśla godność Maryi jako Matki Kościoła i Jej czynną obecność w misterium Chrystusa i Kościoła"1.

Sługa Boży kard. Stefan Wyszyński nie ukrywał radości z ogłoszenia Bożej Rodzicielki Matką Kościoła i już w czasie Soboru powiedział: „Padło oficjalne oświadczenie: Kościół ma Matkę! Matka Chrystusowa jest Matką naszą!"2. Kościół w Polsce wprowadził liturgiczne święto Maryi, Matki Kościoła w 1971 roku. Równocześnie Episkopat Polski wysłał specjalny memoriał do Pawła VI i do wszystkich episkopatów świata, aby święto Matki Kościoła zostało rozszerzone dla Kościoła powszechnego oraz aby wszystkie episkopaty świata oddały swoje Kościoły i ludzkość Maryi Matce Kościoła. Miał to być wyraz jedności Kościoła powszechnego, który w dramatycznej chwili zwraca się do swojej Matki ${ }^{3}$. Dał temu wyraz dopiero Jan Paweł II, najpierw przybywając jako papież na Jasną Górę, aby w czasie swej pielgrzymki potwierdzić, już jako głowa Kościoła, duchową drogę oddania Kościoła w Polsce w niewolę Maryi. W tych okolicznościach nazwał Maryję Jasnogórską Matką Kościoła. Ponadto zwrócił uwagę na szersze niż polskie, tj. powszechne, znaczenie słów milenijnego Aktu Oddania Najświętszej Maryi Pannie, które jest wydaniem za Kościół w świecie zawierającym profetyczny wydźwięk współczesnych dziejów Kościoła i świata. Było to potwierdzenie drogi

1 Wypowiedź Prymasa Polski podczas III sesji Soboru Watykańskiego II w spawie ogłoszenia Maryi Matkq Kościoła i oddania w Jej macierzyńskq opieke Kościoła i całego świata, Rzym 16 IX 1964; w: Matka Odkupiciela Matkq Kościoła, red. Instytut Prymasowski Ślubów Narodu, Warszawa 1990, s. 20.

2 Memoriat Episkopatu Polski do Ojca Świętego Pawła VI w sprawie oddania narodu polskiego Maryi, Matce Kościoła, Wrocław, 1.09.1965 r., w: Matka Odkupiciela Matkq Kościoła, s. 29.

3 Zob. Memoriał Episkopatu Polski do wszystkich episkopatów katolickiego świata o oddaniu świata Maryi Matce Kościoła, w: Matka Odkupiciela Matkq Kościoła, s. 75-86. 
Kościoła, który po II Soborze Watykańskim szukał świateł i mocy dla siebie i dla świata. Dzięki natchnieniu Ducha Świętego było to zarazem nowym odczytaniem ducha tradycji takich świętych jak Bernard z Clairvaux, Ludwik de Montfort czy Maksymilian Maria Kolbe, jak podkreślił to na Jasnej Górze Ojciec Święty . Na kolegialne oddanie świata Matce Bożej czekaliśmy do 1984 roku.

Trzeba zauważyć, na co też wskazywał Jan Paweł II, że w tej obecności Matki Kościoła pośród swojego ludu znajdują się inspiracje do prowadzenia dzieła wychowania i formacji „człowieka nowego" w duchu maryjnym. To oddanie się w niewolę miłości Matce Kościoła Polsce „jest wołaniem serca i woli, wołaniem całego chrześcijańskiego jestestwa osoby i wspólnoty o pełne prawo do głoszenia zbawczej misji, o misji tej wszechstronną skuteczność, o jej nowe zakorzenienie w idącej (i już obecnej) epoce dziejów świata - przez Maryję!"5.

Formacyjne inspiracje do kształtowania konkretnych postaw ducha i moralności wyrastają z przekonania, że śluby czy akty oddania Matce Bożej wciąż domagają się konkretnych odpowiedzi. Rozumiał to bardzo dobrze prymas Wyszyński ${ }^{6}$, który szukał świateł w historycznych przyrzeczeniach, szczególnie tych z lat 1957 i 1966, do dźwigania narodu w górę, do odnowy moral-

4 Por. Jan Paweł II, Tutaj zawsze byliśmy wolni. Homilia na Jasnej Górze 4 IV 1979 r., w: Jasnogórska Bogarodzica w wypowiedziach bł. Jan Pawła II, red. Z. Jabłoński, Częstochowa 2011, s. 41.

5 Tamże, s. 42.

6 W liście z 10 listopada 1955 roku z Komańczy do generała zakonu paulinów o. Alojzego Wrzalika uwięziony prymas pisał: „Bodaj nigdy tak dobitnie, jak teraz nie uświadomiłem sobie tego, jak potężna jest wola Boża, by Jasna Góra była Stolicą chwały Bożej, która rozlewa się na Polskę przez dziewicze dłonie Pośredniczki łask wszelkich. Bodaj nigdy jak teraz nie widziałem tego tak jasno, że wolą Ojca Narodów jest, by Naród polski był zjednoczony przez Jasną Górę i by tutaj się odnawiał i krzepił. Tej woli Bożej nikt nie zdoła złamać, o czym świadczą wieki naszego trwania na Jasnej Górze, bardziej jeszcze niezłomnego niż mury i wały obronne" (S. Wyszyński, Wszystko postawiłem na Maryje, Paris 1980, s. 118). 
nej i społecznej w duchu Ewangelii i chrześcijańskiej Tradycji W liście z Jasnej Góry pisze: „Oczekujemy takich ludzi, którzy obok spraw osobistych, dostrzegać będą wielkie problemy ogólne, rozszerzą swoje serca i w poczuciu odpowiedzialności za Kościół i za katolickie oblicze Polski drugiego tysiąclecia, podejmą dzieło współpracy apostolskiej przez modlitwę, ofiarę i działanie, którzy staną się «Pomocnikami Maryi» na rzecz Kościoła i Jej Syna"8.

Odwołując się do obecności Bożej Rodzicielki w misterium Chrystusa i Kościoła, prymas znalazł konkretny sposób i styl współdziałania: Maryja jako pomoc i obrona, a chrześcijanin jako pomocnik Maryi w Kościele. W latach siedemdziesiątych $\mathrm{XX}$ wieku na fali odnowy soborowej i przy jednoczesnych ograniczeniach wynikających z agresywnej polityki i prześladowań ze strony władz komunistycznych rodzi się dzieło „Pomocników Maryi Matki Kościoła" . Od samego początku zarówno idea, jak i samo dzieło było ukierunkowane na pomaganie żyjącemu w swoim Kościele Chrystusowi na wzór Maryi i przez współpracę z Maryją, Matką Kościoła. Te inspiracje formacyjne da się zauważyć w wymiarze osobistym, eklezjalnym i społecznym.

\section{Najświętsza Maryja Panna Matką Kościoła w wymiarze osobistym}

W liście, w którym ogłaszano święto Matki Kościoła na terenie Polski, pasterze zachęcali do podjęcia egzystencjalnej - osobistej

7 Zob. M. Okońska, Wszystko postawił na Maryje, Warszawa 2007, s. 36-46.

8 List pasterski Prymasa Polski, Stefana kardynała Wyszyńskiego wzywajacy ludzi dobrej woli do pomocy Kościołowi i chrześcijańskiej ojczyźnie przez Bogurodzicę Matkę Kościoła. Jasna Góra 26 VIII 1969 r., w: Matka Odkupiciela Matką Kościoła, s. 47.

9 Zob. tamże, s. 46-51; por. List pasterski Episkopatu Polski wzywajacy wiernych do dzieła Pomocników Matki Kościoła, 9 II 1972 r., w: Matka Odkupiciela Matkq Kościoła, s. 94-99. 
relacji i więzi z Maryją jako swoją Matką. Było to wprowadzanie w przestrzeń nauczania soborowego o macierzyństwie Maryi. Więź z Matką Kościoła wpisuje się doskonale w tęsknotę współczesnego człowieka: „Matka Kościoła jest w szczególny sposób Matką moją. Bo przecież ja jestem cząstką Chrystusowego Ciała, jestem Kościołem Bożym. Ogłoszenie święta Matki Kościoła, to ogłoszenie święta mojej Matki i przypomnienie, ja mam taką Matkę! Już nie jestem sam. Czy moja ziemska matka żyje, czy nie, mam Matkę, która nie umiera, zawsze jest przy mnie!"10.

Kardynał Karol Wojtyła w komentarzu do milenijnego Aktu oddania Polski w macierzyńską niewolę Maryi Matki Kościoła, za wolność Kościoła Chrystusowego ${ }^{11}$, odsłania misterium, jakie dokonuje się w sercu każdego człowieka. W jego duszy przez łaskę chrztu dokonuje się tajemnica zbawienia: staje się on członkiem Kościoła, a więc „nie należy już do samego siebie” (por. 1 Kor 6,19), ale do Tego, który za niego umarł i zmartwychwstał (por. 2 Kor 5,15). Przez przyjęcie chrztu człowiek staje się również własnością Maryi, Matki Kościoła, jakby Jej niewolnikiem (por. 1 Kor 7,22-23). Jako dziecko Maryi „należące do Chrystusa" (por Rz 8,14-1) jest również Jej dzieckiem - włączanym w Jej macierzyńską niewolę miłości (rodzaj zależności, podlegania), czyli w prawa Matki Kościoła do dzieci Kościoła ${ }^{12}$.

${ }^{10}$ List pasterski Episkopatu Polski ogłaszający w Polsce święto Maryi, Matki Kościoła. Jasna Góra 4 V 1971, w: Matka Odkupiciela Matkq Kościoła, s. 64.

11 Zob. Akt oddania Polski w macierzyńskq niewole Maryi, Matki Kościoła, za wolność Kościoła Chrystusowego, złożony 3 maja 1966 roku na Jasnej Górze z okazji Millennium Chrztu Polski. Umieszczony jako wotum w srebrnej tubie przy ołtarzu w kaplicy Cudownego Obrazu. Odnawiany w sanktuarium jasnogórskim i wszystkich kościołach w Polsce w uroczystość Królowej Polski, 3 maja, zob. S. Wyszyński, Na drogach zawierzenia, Warszawa 1996, s. 23-26.

12 Kardynał Karol Wojtyła w swoim komentarzu odwołuje się do nauczania Konstytucji o Kościele, w której w 53. punkcie, nawiązując do słów św. Augustyna, mówi, że Maryja „złączona jest ze wszystkimi ludźmi, którzy mają być zbawieni, pochodzeniem z rodu Adama, a co więcej, jest «zgoła 
Przebywając w Kościele, „nowy odkupiony człowiek” powoli poznaje sposób realizacji tej nowej wolności, bo po grzechu pierworodnym ustanowione zostały swego rodzaju „ramy”, aby nie wypaść z drogi wolności dziecka Bożego. W Kościele człowiek ochrzczony jest przygotowywany do podjęcia tzw. drogi nowej wolności, czyli przyjęcia odpowiedzialności za wzrastanie $w$ wierze i jednoczenie się z Chrystusem. W ten sposób każdym swoim wolnym wyborem potwierdza przynależność do Chrystusa albo przez nieposłuszeństwo zaprzecza wolności „synostwa Bożego”. Ostatecznie w całej swojej osobistej wolności, rozpoznając Miłość Boga, poddaje się „niewoli miłości Chrystusa”. Dlatego „oddanie się w niewolę miłości" nie jest pozbawieniem wolności, ale prośbą o to, by jej używać w pełni świadomie i dobrowolnie oraz dogłębnie uporządkować wolną wolę w odniesieniu do Boga Stwórcy i Odkupiciela ${ }^{13}$.

Święty Ludwik Grignion de Montfort, w swoim Traktacie o prawdziwym nabożeństwie do Najświętszej Maryi Panny podkreśla, że oddanie się Maryi „w świętą niewolę miłości jest najwyższą formą czci wobec Matki Chrystusa i Kościoła ${ }^{14}$. Ten akt osobistego oddania ma formę deklaracji, oświadczenia i postanowienia. Staje się też sposobem życia, wybranym przez konkretną osobę podczas składania, ponawiania czy też trwania w podjętej decyzji oddania się Maryi. Taki duchowy akt oddania nie pozbawia

matką członków (Chrystusowych), [...] ponieważ miłością swoją współdziała w tym, aby wierni rodzili się w Kościele, którzy są członkami owej Głowy»? (Św. Augustyn, De S. Virginitate). Dlatego to doznaje Ona czci jako najznakomitszy i całkiem szczególny członek Kościoła i jako jego typiczne wyrażenie oraz najdoskonalszy wzorzec wiary i miłości, Kościół też katolicki pouczony przez Ducha Świętego darzy Ją synowskim uczuciem czci jako Matkę najmilszą" (Konstytucja dogmatyczna o Kościele, 53, w: Sobór Watykański II. Konstytucje, Dekrety, Deklaracje; Poznań 1968, s. 158). Zob. Komentarz teologiczno-duszpasterski Metropolity krakowskiego, abp. Karola Wojtyty, do aktu dokonanego na Jasnej Górze 3 maja 1966 r., w: Matka Odkupiciela Matkq Kościoła, s. 44.

${ }^{14}$ Św. Ludwik Grignion de Montfort, Traktat o prawdziwym nabożeństwie do Najświętszej Maryi Panny, Warszawa 1997, s. 135. 
człowieka osobistej wolności, ale prowadzi do aktywności życiowej. W tym właśnie akcie, jak pisze kard. Karol Wojtyła, chodzi o to, że „chrześcijańskie - skoro ma być «prawdziwą pomocą Kościołowi powszechnemu ku budowaniu Ciała Chrystusowego na ziemi» - nie może być byle jakie, mierne, przeciętne czy niekonsekwentne. Akt jasnogórski zawiera pośrednie zobowiązanie do stałego umacniania i pogłębiania tego życia"15.

Przyszły papież kard. Wojtyła w swoim komentarzu konkluduje, uspokajając zarówno pasterzy, jak i wiernych, że Akt oddania w niewolę miłości Matce Bożej nie jest źródłem jakichś nowych czy szczególnych zobowiązań w porównaniu z tymi, jakie wypływają z chrztu świętego czy z faktu bycia chrześcijaninem. One dają konkretny sposób ich realizowania. Tym bardziej że „wskazują drogę doświadczeń związanych z całą historią zbawienia i z historią zbawienia na ziemi polskiej w szczególności. Akt jasnogórski daje temu wyraz, a zarazem owo doświadczenie przeszłości - niejako polskie doświadczenie drogi zbawienia - stara się ująć w sposób bardziej teologiczny. Przez to zaś, że wskazuje konkretne sposoby realizowania tych zobowiązań, jakie wynikają ze chrztu i stanowią o życiu autentycznie chrześcijańskim. W ten sposób nabiera również szczególnego znaczenia duszpasterskiego"16.

Idąc śladami tej drogi, potrzebujemy przypomnieć, że już polscy jezuici w XVI wieku, mówiąc o oddaniu się Matce Bożej w niewolę, piszą o „pętku Maryi”. Świadectwa świętych, a szczególnie świadectwa pielgrzymów jasnogórskich, mówią o tym, czym jest oddanie Maryi i jakie owoce rodzi w służbie dla Kościoła. Do tej właśnie drogi doświadczenia wiary i zaufania Matce Bożej i Kościoła w Polsce odwoływał się prymas Wyszyński. Mówi o tym zarówno w swoim duchowym oddaniu się Maryi, jak i w listach i przemówieniach do Kościoła w Polsce, do papieży, na Soborze i do biskupów świata.

${ }^{15}$ Komentarz teologiczno-duszpasterski Metropolity krakowskiego, abp. Karola Wojtyty do aktu dokonanego na Jasnej Górze 3 maja 1966 r., s. 43.

16 Tamże. 
Przywołajmy tu kilka przykładów takiego osobistego oddania, zainspirowanego pośrednictwem Najświętszej Maryi Panny: św. Maksymilian Maria Kolbe, św. Jan Paweł II, sługa Boży Stefan kard. Wyszyński.

Święty Maksymilian Maria Kolbe pisze z Japonii do braci zakonnych w Niepokalanowie: „Każda myśl, słowo, cierpienie Niepokalanej były jak najdoskonalszym aktem miłości Bożej, miłości Jezusa. Trzeba by więc powiedzieć duszom i to wszystkim i każdej z osobna, co są i będą aż do skończenia świata, powiedzieć przykładem, słowem żywym, pisanym, drukowanym, radiowym, malowanym, rzeźbionym itd., co i jak Niepokalana w konkretnych okolicznościach bieżącego życia, różnych stanów by myślała, mówiła, czyniła, żeby najdoskonalsza miłość, miłość Niepokalanej aż ku Bożemu Sercu rozpłomieniała na ziemi"17.

Z kolei św. Jan Paweł II wyznaje: „Był taki moment, zdawało mi się, że powinienem odsunąć się nieco od dziecięcej pobożności maryjnej, a nawet poniekąd zakwestionowałem swoją pobożność maryjną uważając, że posiada ona w sposób przesadny pierwszeństwo przed nabożeństwem do samego Chrystusa. Muszę przyznać, że wówczas z pomocą przyszła mi książeczka św. Ludwika Marii Grignion de Montfort, nosząca tytuł: «Traktat o prawdziwym nabożeństwie do Najświętszej Maryi Panny». W książeczce tej znalazłem poniekąd gotową odpowiedź na moje pytania. Tak, Maryja nas przybliża do Chrystusa, prowadzi nas do Niego, ale pod warunkiem, że przeżyjemy Jej tajemnice w Chrystusie. [...] Tak więc nauczyłem się na nowo Maryjności i ten dojrzały kształt nabożeństwa do Matki Bożej idzie ze mną od lat"18.

Sługa Boży Stefan kard. Wyszyński na kilka dni przed śmiercią pisał: „Staję na progu Kaplicy Jasnogórskiej i tam zawszę chcę być, choćby mnie wszyscy potrącali. Jestem związany z Jasną

17 List z dnia 30 X 1935 r., Nagasaki, Mugenzai no Sono, „Rycerz Niepokalanej" 25 (1951), s. 115, por. https://niepokalanow.pl/569-do-niepokalanowa/ [data dostępu: 21.11.2019].

18 Jan Paweł II, Przekroczyć próg nadziei, Lublin 1994, s. 157. 
Górą teraz i zawsze. Staję w łączności z Ojcem świętym, z całym Kościołem i składam hołd czci i miłości Jasnogórskiej Matce Kościoła. Postawiłem wszytko na Nią i jej to zawdzięczam, że miłosierdzie Boże towarzyszyło mi zawsze i wszędzie, a szczególnie w najtrudniejszych chwilach życia. [...] Na mojej drodze stanęła Jasnogórska Matka Kościoła, której stałem się wiernym niewolnikiem i zawsze na tym dobrze wychodziłem. Per Mariam omnia soli Deo - było dla mnie zawsze radosną konsekracją codziennego życia”. Następnego dnia dodał: „Nie piszę testamentu pastoralnego. Przyjdą nowe czasy, wymagają nowych świateł, nowych mocy, Bóg je da w swoim czasie. Pamiętajmy, że jak kardynał Hlond, tak i ja, wszystko zawierzyłem Matce Najświętszej i wiem, że nie będzie słabszą w Polsce, choćby ludzie się zmieniali" ${ }^{\prime 19}$.

Należy z wdzięcznością podkreślić, że Kościół katolicki ze szczególną troską nosi w swojej tradycji i doświadczeniu duchowym bogactwo form pobożności maryjnej, które są wyrazem osobistej miłości do Maryi jako Matki. Oprócz nowych inspiracji dla osobistej formacji duchowej skutecznym narzędziem łaski są nadal: różaniec, szkaplerz, litanie, nabożeństwa, pielgrzymka do sanktuariów, akt osobistego oddania Maryi. Idąc śladami komentarza kard. Karola Wojtyły do milenijnego Aktu oddania, należy wiedzieć, że „nabożeństwo do Matki Najświętszej stanowi niewątpliwie wielki kapitał religijny w duszach polskich. Dowodem tego było i jest nawiedzenie obrazu, dowodem był rok milenijny. Nabożeństwo to istnieje w postaci bardzo uczuciowej, do której pobudza sama osobowość Matki" ${ }^{20}$. Arcybiskup z Krakowa, zauważając potrzebę odnowy soborowej, jednak w związku z przeobrażeniami w religijności polskiej, podkreśla potrzebę nadawania temu nabożeństwu postaci bardziej refleksyjnej. Konkretyzuje, pisząc: „Na drodze refleksji zwyczajna droga nabożeństwa do Matki Najświętszej, droga per Mariam ad Jesum,

19 S. Wyszyński, Na drogach zawierzenia, s. 197-198.

20 Komentarz teologiczno-duszpasterski Metropolity krakowskiego, abp. Karola Wojtyty do aktu dokonanego na Jasnej Górze 3 maja 1966 r., s. 45. 
winna być wspierana i uzupełniana drogą per Jesum ad Mariam. Poznanie Matki, a w związku z tym także pełna Jej chwała, dokonuje się poprzez poznanie Syna oraz Jego dzieł - tych, w których Matka uczestniczyła" ${ }^{21}$. A to prowadzi do osobistego zaangażowania w dzieło ewangeliczne Kościoła. Brak tych wyraźnych przekonań zaangażowania się w treść i ducha Aktu oddania się w niewolę oraz brak konsekwencji katolickiej w życiu poszczególnych chrześcijan osłabia wolność Kościoła i realizację jego misji - bycia solą i światłem.

\section{Najświętsza Maryja Panna jako Matka w życiu Kościoła}

Świat współczesny zapragnął na nowo zobaczyć Kościół; Kościół, w którym żyje i działa Chrystus w swoim ludzie. Obecność najświętszej Maryi Panny przy Chrystusie dawała nadzieję Kościołowi w Polsce, gdy ogłaszał święto Matki Kościoła na terenie naszej ojczyzny. Przemiany, jakie dokonywały się w świecie, i komunizm paraliżujący życie Polaków, nakazywały „otworzyć drzwi" na odnowiony obraz i wizję Kościoła. Biskupi polscy szli drogą odnowy, kontynuując podjęty wcześniej maryjny program. Wynikało z niego jasne przesłanie: „Maryja nie jest tylko postacią historyczną, która wypełniła już swoje zadanie. Ona żyje w Kościele, działa z Chrystusem w dziele odkupienia rodziny ludzkiej. W ramionach tych dwojga: Jezusa i Maryi, znajduje się lud Boży: papież, biskupi, kapłani, zakony, cała hierarchia i świeccy rodzice, młodzież i dzieci"22.

Ratunkiem i mocą dla Kościoła w Polsce i w świecie współczesnym, jak zaświadczał kard. Wyszyński, była jego osobista

\section{Tamże.}

${ }^{22}$ List pasterski Episkopatu Polski ogłaszajacy w Polsce święto Maryi, Matki Kościoła. Jasna Góra 4 V 1971, s. 64. 
więź z Jasnogórską Królową, o czym świadczą wielowiekowe świadectwa trwania w wierności nauczaniu Kościoła przez jego pasterzy. Dlatego prymas nie ustawał w prowadzeniu niemalże bohaterskiego programu duszpasterzowania. Najpierw przez ofiarę $\mathrm{w}$ więzieniu, potem przez śluby jasnogórskie, przez prowadzenie wielkiej - dziewięcioletniej Nowenny przed Millennium Chrztu Polski, peregrynację Wizerunku Królowej Polski, Akt oddania biskupów, diecezji i narodu w niewolę Matce Najświętszej. Miał bowiem głębokie przekonanie, że to związanie wszystkiego w Kościele z jego Matką nie tylko „zabezpieczy” jego dalsze trwanie, ale Jej obecność rozpali serca członków Kościoła, wskazując na żyjącego w swoim ludzie Chrystusa. Była to olbrzymia praca katechetyczna i mistagogiczna. Liczne wypowiedzi prymasa, zwłaszcza na Jasnej Górze, a potem w czasie trwania Millennium, pomagały udręczonemu komunizmem Ludowi Bożemu zrozumieć, że jest wspólnotą Kościoła, żyjącym na ziemi Jezusem; że ten Kościół ma Głowę i członki. W tej formacji: nauczaniu i wtajemniczaniu w misterium Kościoła, szczególnie ważne było odniesienie do Jasnogórskiej Matki. Tą szczególną wrażliwość dobrze oddają słowa powieści Potop Henryka Sienkiewicza. Autor wkłada w usta wielkiego obrońcy Jasnej Góry, ojca Augustyna Kordeckiego, wyznanie: „Szydzi i pogardza nami nieprzyjaciel, mówiąc cóż nam z naszych cnót zostało. A ja powiadam wszystkie poginęły. Lecz pozostała cześć i miłość do Najświętszej Panienki, na którym to fundamencie reszta odbudowana być może"23.

W podobnym duchu piszą ku pokrzepieniu serc w czasie zaborów i niewoli Adam Mickiewicz, Juliusz Słowacki, ale też pasterze Kościoła jak św. Józef Bilczewski, św. Sebastian Pelczar, bł. Honorat Koźmiński, którzy odwołują się do żywej więzi z Bożą Rodzicielką, Królową Narodu Polskiego, która doprowadzi do zmartwychwstania. Miłość do Bożej Matki, jak mówił na

${ }^{23}$ H. Sienkiewicz, Potop, t. 3, Warszawa 1888, s. 217. 
soborze prymas Wyszyński, ocaliła Kościół w Polsce od zalewu protestacji, budząc wiarę do wytrwania przy Kościele i przykazaniach. Na szczęście odnowa soborowa Kościoła w Polsce, mimo złych doświadczeń z innych krajów Europy, nie zerwała i nie wygasiła miłości oraz oddania wobec Matki, Pośredniczki i Wspomożycielki, pomocy i obrony.

Należy zauważyć zwiększającą się wciąż obecność na ziemiach polskich sanktuariów maryjnych. Daje to okazję do formacji maryjnej i mariologicznej, stwarza przestrzeń dla duchowości maryjnej. Nie można również zapomnieć o świadectwie czci wobec obrazów czy figur maryjnych, z którymi przybyli Polacy ze Wschodu, także nasi rodacy emigrujący za chlebem albo z powodu wojen zabierali ze sobą wizerunek Maryi, ruszając do Stanów Zjednoczonych czy Australii. Wzrasta liczba pielgrzymek i pielgrzymów na Jasną Górę, do Kalwarii Zebrzydowskiej, Lichenia czy innych miejsc kultu Maryi i świętych. Zapewne również pośród inspiracji maryjnych na terenach Kościoła w Polsce należy pokreślić rolę maryjnych pasterzy, którzy w różny sposób kontynuują dawne maryjne tradycje, a niektóre z nich odnawiają, angażując dzieci, młodzież i dorosłych. Są to grupy, stowarzyszenia czy wspólnoty maryjne oraz różne dzieła. W nich dokonuje się formacja maryjna do świadomego uczestniczenia we wspólnocie Kościoła.

Przykładem może być moje osobiste doświadczenie z czasów duszpasterstwa w jednej z parafii - sanktuarium we Wrocławiu. Zapewne jest ono również bliskie wielu kapłanom. W latach dziewięćdziesiątych metropolita wrocławski kard. Henryk Gulbinowicz prosił, aby kościół parafialny pw. św. Antoniego we Wrocławiu, do którego przybyła kopia ikony Matki Bożej Jasnogórskiej i ojcowie paulini, stał się tzw. małą Jasną Górą. Dziś, po ponad dwudziestu latach obecności i posługi paulińskich duszpasterzy, można powiedzieć, że jest to miejsce działania Maryi jako Matki, pomagającej odzyskać przybywającym tam na modlitwę godność dziecka Bożego. Tak wielu mogło tam doświadczyć żywej wspól- 
noty Kościoła, angażując się w formację duchową, wspólnotową i modlitewną. Świątynia ta stała się sanktuarium Jasnogórskiej Matki Kościoła i może służyć jako przykład maryjnej ewangelizacji. Modlitwa przed Najświętszym Sakramentem oraz miłość do Maryi, Matki Kościoła, prowadzą do spotkania z Bogiem, do przemiany serc i życia osób przybywających do tej świątyni. Duch przemiany - ewangelicznej Kany Galilejskiej, nakłania do sakramentu pojednania i powrotu do jedności z Kościołem. Osoby pragnące dojrzewać do pełni łaski chrztu mogą korzystać z różnych form i charyzmatów grup oraz wspólnot tworzących parafie.

W Księdze łask otrzymanych przez wstawiennictwo Jasnogórskiej Matki Kościoła w sanktuarium pewna osoba zapisała swoje świadectwo: „Przed obrazem Maryi we wrocławskiej małej Jasnej Górze doświadczyłam szczególnej łaski. Moje życie wyglądało jak ruina: śmierć synka, niesakramentalny związek, szukanie pomocy u wróżek i bioenergoterapeutów itp. Po jednym ze spotkań modlitewnych doznałam czegoś, co zmieniło moje życie. Przygotowując się do spowiedzi z całego mojego życia, przychodziłam właśnie przed obraz Matki Bożej i w Jej Sercu szukałam wskazówek i pomocy. Od tamtej chwili, kiedy to oczyszczona z tego okrutnego ciężaru grzechów, układów, uzależnień, kiedy to poczułam się taka lekka, taka nowa, inna, już cała w ręku Boga, wiedziałam już jedno, że nigdy, przenigdy nie chcę jakichkolwiek uwikłań w niewolę zła. Tej odwagi, zawierzenia szukałam właśnie tu u Matki Bożej i do dziś, w każdej sytuacji, i tej smutnej, i radosnej biegnę do Niej, tuląc się do Jej Serca, szukam ukojenia, wskazówek, aby iść dalej, jako już Jej córka"24.

Na szczęście bohaterski maryjny program duszpasterzowania, prowadzony przez prymasa Wyszyńskiego, trwa. Podejmują go pasterze i świeccy, często głęboko oddani Maryi. Biorą oni na siebie $\mathrm{z}$ dużą gorliwością trud wychowania do naśladowania Maryi w Jej drodze służenia Jezusowi Chrystusowi w Kościele. To

${ }^{24}$ Księga łask otrzymanych za pośrednictwem Jasnogórskiej Matki Kościoła, sanktuarium we Wrocławiu przy ul. św. Antoniego 13. 
zadanie jest tak ważne dzisiaj, aby z oddaniem, ale też właściwie zaangażować się w życie wspólnoty Kościoła. Należy więc wciąż przypominać biblijne i eklezjalne drogi, które wyraźnie akcentował II Sobór Watykański, zwłaszcza w VIII rozdziale Konstytucji Lumen gentium. Tą drogą idzie, można powiedzieć, Akt jasnogórskiego oddania, powtarzany uroczyście w kościołach 3 maja. Jest on wciąż aktualny i zawiera wiele inspiracji do naśladowania Najświętszej Maryi Panny jako Matki Kościoła. „Prawdziwe więc nabożeństwo do Maryi musi przejawiać się jako umiłowanie Kościoła, rzetelna odpowiedzialność za Kościół w każdym zakresie. Angażując się w dzieło Chrystusa Pana, poczuwając się do odpowiedzialności za Kościół, musimy co krok zawierzać bez reszty Najświętszej Wspomożycielce. Wydaje się, że to jest właśnie duch Aktu jasnogórskiego, którym trzeba stopniowo - zarówno dyskretnie jak skutecznie - przepajać całe duszpasterstwo i apostolstwo świeckich. Na tym też będzie polegała realizacja Aktu milenijnego"25.

\section{Maryja Matką Kościoła w życiu społecznym}

W 2014 roku minęło 50 lat odkąd papież Paweł VI ogłosił Maryję Matką Kościoła, a ponad 40 lat, od kiedy Episkopat Polski z radością ustanowił Jej święto na terenie naszej ojczyzny. Tak wiele zmieniło się przez te lata w życiu społecznym Polski i świata. Doświadczenie wiary potwierdza nam, że dokonało się wiele cudów i zwycięstw, które Bóg uczynił za sprawą Matki Bożej w oddanym jej narodzie. Ale równocześnie postępujący proces laicyzacji wyprowadza współczesnego człowieka nie tylko ze wspólnoty czy jedności z Kościołem, ale czyni go również osobą nieumiejącą żyć w przestrzeni życia społecznego. W liście z 1971 roku pasterze

${ }_{25}$ Komentarz teologiczno-duszpasterski Metropolity krakowskiego, abp. Karola Wojtyty do aktu dokonanego na Jasnej Górze 3 maja 1966 r., s. 45. 
Kościoła w Polsce tak wyraźnie podkreślali prawdę, że „światu współczesnemu potrzeba Matki. Ludzkość dzisiejsza tęskni do Matki bardziej niż kiedykolwiek. Wszyscy zaczynamy tęsknić do «ludzkiego» człowieka i «ludzkiej» kultury, do prawdziwego humanizmu"26.

Dziś walka o człowieka i społeczeństwo idzie tymi samymi drogami jak w chwili pisania ślubów jasnogórskich: dochodzi do zagrożenia życia, zwłaszcza nienarodzonych i osób starszych, troski o rodzinę, a szczególnie o godność kobiety, o przyszłość polskiego narodu, o młodzież oraz do walki z wadami narodowymi. Pomocnicy Maryi, oddani i uformowani w Jej duchu, w służbie współczesnemu społeczeństwu mogą wciąż wskazywać na źródło godności człowieka, jego pokoju, możliwość przebaczenia i pojednania, które zawsze przychodzi przez ofiarowaną w Jezusie miłość. Wracamy do prymasowskiego programu: „Gdzież jest szkoła takiej miłości? Odpowiedz jest bardzo jasna: w macierzyńskich ramionach Matki Jezusowej, Matki Kościoła, Matki Rodziny człowieczej. Trzeba przywrócić świadomość posiadania Matki naszemu Narodowi, Kościołowi, Rodzinie ludzkiej. Może wtedy nieludzki świat stalowych potęg, zamieni się w świat prawdziwie ludzki, którego prawem będzie miłość, nie groza i lęk!... Ona czuwa nad naszą wiarą i życiem $\mathrm{z}$ wiary, którego prawem naczelnym jest miłość, wymagająca nieraz ofiary z siebie na rzecz innych"27.

Akt oddania Matce Bożej w niewolę miłości jest wciąż pomocą w rozpoznawaniu fałszywych idei i ideologii, które odrzucając Boga, prowadzą współczesne społeczeństwa do niewoli, jaką jest indywidualizm i hedonizm. We współczesnym zamęcie również osoby ochrzczone poddawane są próbom wyborów postaw: pomiędzy służbą a postawą osobistego czy społecznego egoizmu, tryumfalizmu, tymczasowości i niezależności, życia w związkach na próbę, życia w postawie tzw. singla, lęku przed

\footnotetext{
${ }^{26}$ List pasterski Episkopatu Polski ogłaszajacy w Polsce święto Maryi, Matki Kościoła. Jasna Góra 4 V 1971, s. 65.

27 Tamże.
} 
odpowiedzialnością aż po różnorodne przejawy homoseksualizmu. O skutkach tej złej drogi mówił m.in. papież Franciszek w przemówieniu do Forum Rady Europy: „Bez poszukiwania prawdy każdy staje się miarą samego siebie i swoich działań, torując drogę do subiektywistycznego potwierdzenia praw, tak, że pojęcie praw człowieka, które samo w sobie ma wartość uniwersalną, zastępuje się ideą prawa indywidualistycznego. Prowadzi to do zasadniczego niedostrzegania innych i promowania owej globalizacji obojętności, jaka rodzi się z egoizmu, jako owoc koncepcji człowieka niezdolnego do przyjęcia prawdy i życia autentycznym wymiarem społecznym"28. Duch indywidualizmu i hedonizmu jest zupełnie obcy duchowi maryjnemu, do którego przez pokolenia wychowywała Polaków Królowa Polski. Oczywiście w naszej historii mamy wiele świadectw, w których nieposłuszeństwo i niedotrzymanie wierności Bogu i ślubom maryjnym kończyły się dramatami społecznymi. Przez cały okres zaborów uważano m.in., że niewola jest skutkiem niewypełnienia ślubów królewskich.

Również dziś, tak jak w minionych okresach, budzą się wątpliwości i pokusy związane $z$ wiernością ślubom i oddaniem narodu polskiego Maryi, Matce Kościoła. Prymas Wyszyński, a następnie Jan Paweł II, wskazywali na Królową Polski i Jej jasnogórski tron jako miejsce wielkiej nadziei - wielkiego zawierzenia. Oczywiście oddanie w niewolę miłości za wolność Kościoła w świecie wymaga wciąż od człowieka nowych prób wiary, aby dać nadzieję nowego zwycięstwa Maryi - i nowej wolności. W sanktuarium jasnogórskim znajduje się codziennie tak wiele świadectw przemiany, potwierdzeń Jej obecności i duchowych zwycięstw za Jej wstawiennictwem. „Ona tyle razy już zwyciężała!”- jak często powtarzał prymas Stefan Wyszyński!

${ }^{28}$ Franciszek w przemówieniu do Forum Rady Europy, 25 XI 2014 r., https://www.radiomaryja.pl/kosciol/przemowienie-papieza-franciszka-wygloszone-na-forum-rady-europy/. 
Pielgrzymowanie na Jasną Górę ponad czteromilionowej rzeszy wiernych z Polski i zagranicy jest wielkim świadectwem jakiegoś „narodowego nabożeństwa” do Najświętszej Maryi Panny, Matki Kościoła. Stanowi ono niewątpliwie wielki kapitał religijny w duszach Polaków. Każdego dnia rodzice przyprowadzają przed oblicze swojej Królowej niemowlęta i dzieci pierwszokomunijne, nauczyciele i katecheci - gimnazjalistów czy maturzystów, kapłani - wspólnoty studentów oraz całe rzesze różnych grup stanowych i zawodowych. „Nabożeństwo do swojej Matki i Królowej” $\mathrm{z}$ jednej strony istnieje w Polakach w sferze przeżyć i emocji, do czego pobudza spotkanie w Jej domu. Z drugiej strony Maryja jako Matka chce wszystkich i każdego doprowadzić do tzw. maryjności dojrzałej. To był i jest cel formacyjny i katechetyczny nauczania pasterzy Kościoła w Polsce. W czasie Wielkiej Nowenny kard. Wojtyła pisał: „Poznanie Matki, a w związku z tym także pełna Jej chwała, dokonuje się poprzez poznanie Syna oraz Jego dzieł - tych, w których Matka uczestniczyła" ${ }^{29}$. Potem do tej duchowej drogi odwoływał się wielokrotnie już jako papież Jan Paweł II podczas wszystkich pielgrzymek do jasnogórskiego sanktuarium. Przypominał o najważniejszym sensie oddania w niewolę miłości. W 1979 roku na Jasnej Górze mówił: „Słowo «niewola» tak dotkliwe dla nas, Polaków, kryje w sobie podobny paradoks, jak słowa Ewangelii o własnym życiu, które trzeba stracić, ażeby je zyskać (por. Mt 10,39). Wolność jest wielkim darem Bożym. Trzeba go dobrze używać. Miłość stanowi spełnienie wolności, a równocześnie do jej istoty należy przynależeć. [...] Niewola miłości wskazuje na szczególną zależność, na świętą zależność i na bezwzględną ufność. Bez tej zależności świętej, bez tej ufności heroicznej, życie ludzkie jest nijakie"30.

29 Komentarz teologiczno-duszpasterski Metropolity krakowskiego, abp Karola Wojtyły do aktu dokonanego na Jasnej Górze 3 maja 1966 r., s. 45.

30 Jan Paweł II, Tutaj zawsze byliśmy wolni. Homilia na Jasnej Górze 4 VI 1979 r., w: Jasnogórska Bogarodzica w wypowiedziach bł. Jan Pawła II, s. 41 . 
Praktyka prawdziwego oddania się Maryi prowadzi do zrozumienia tego, o co Matce Bożej zawsze chodzi: o świadome zaangażowanie się człowieka w dzieło Jej boskiego Syna, Jezusa Chrystusa. Ono ma zawsze charakter wspólnotowy i społeczny. Wychowanie w prawdziwym odniesieniu i nabożeństwie do Matki Najświętszej odbywa się zawsze w postawach i dziełach wyrażających się miłością i troską do Kościoła, w posłuszeństwie jego nauczaniu, odpowiedzialności za Kościół w każdym jego zakresie. Kardynał Wojtyła jako niewolnik Maryi zauważa w swoim komentarzu dotyczącym Aktu oddania, że ten sposób odniesienia z miłością do Kościoła potwierdzają święci. Oni, jako maryjni naśladowcy, zdecydowanie stwierdzają, że angażowanie się w dzieło i misję Chrystusa wymaga ustawicznego zawierzania: "Co krok zawierzać bez reszty Najświętszej Wspomożycielce" ${ }^{31}$. Potrzebujemy w wychowaniu i formacji powracania do inspiracji oraz do motywów zawartych w Przyrzeczeniach jasnogórskich, aby jak znaczył kard. z Krakowa, przepajać nimi całe duszpasterstwo i apostolstwo świeckich ${ }^{32}$.

Oczywiste jest, że w drodze do ludzkiej, a tym bardziej duchowej wolności, do czego prowadzi Akt milenijny oddania Maryi, potrzebny jest konkretny wysiłek. On jest potrzebny, aby cały Kościół, a w nim jego członkowie, żyli intensywnym i autentycznym życiem. Akt milenijny podkreślił, że wolność Kościoła w Polsce jest dla wolności Kościoła w świecie współczesnym problemem kluczowym. Dlatego im więcej ludzi będzie w nim świadomie uczestniczyć, tym też będzie on skuteczniejszy. Co ważne, wysiłek, który zawsze towarzyszy walce duchowej, musi być „zasilany” wielką nadzieją. Dlatego potrzeba stałej postawy zawierzenia jako nieustannego odnawiania oddania. Właśnie z takiej wewnętrznej postawy rodzi się prawdziwe nabożeństwo do Matki Najświętszej, z którego Akt jasnogórski wyrósł i do

${ }^{31}$ Komentarz teologiczno-duszpasterski Metropolity krakowskiego, abp. Karola Wojtyły do aktu dokonanego na Jasnej Górze 3 maja 1966 r., s. 45.

32 Tamże, s. 43. 
którego prowadzi ${ }^{33}$. Praktyka prawdziwego nabożeństwa do Najświętszej Maryi Panny, a szczególnie jej zawierzenia jest źródłem nadziei i prawdziwej wolności. Każde prawdziwe zawierzenie inspiruje do nowych inicjatyw, dając potrzebną wytrwałość dla stałych postaw wolnościowych w wymiarze społecznym.

\section{Pomocnicy Maryi Matki Kościoła}

W 2019 roku przypada 50. rocznica powstania Ruchu Pomocników Matki Kościoła. Jego inicjatorem był sługa Boży kard. Stefan Wyszyński, który odczytał w nowatorski sposób realizację idei zawartych w nauczaniu II Soboru Watykańskiego w odniesieniu do Maryi. Zabiegał bardzo, aby papież ogłosił Maryję, Matką Kościoła, co się stało faktem, na zakończenie Soboru. Wskazania soborowe, gdy była mowa o Kościele, wzywały cały lud Boży do odpowiedzialności za Kościół i do współpracy z nim dla rozszerzania królestwa Chrystusowego na ziemi ${ }^{34}$. Dotyczyło to przede wszystkim potrzeby odnowy misji Kościoła przez zaangażowanie świeckich. Pasterze Kościoła w Polsce odczytali to jako pilne zadanie duszpasterskie: przygotować katolików świeckich do włączenia ich w czynną działalność apostolską, w ścisłą współpracę z biskupami i kapłanami, zarówno diecezjalnymi, jak i zakonnymi.

Prymas Stefan Wyszyński i kard. Karol Wojtyła zauważyli, że ogłoszenie Najświętszej Maryi Panny Matką Kościoła jest impulsem do naśladowania Matki Bożej w Jej misji pomagania Chrystusowi żyjącemu w świecie. Najświętsza Dziewica stała się więc obrazem i wzorem misji apostolskiej. Kardynał Wyszyński wyprowadził $\mathrm{z}$ duchowego fundamentu doświadczenia Kościoła

${ }_{33}$ Zob. tamże, s. 45.

34 Por. Konstytucja dogmatyczna o Kościele i Dekret o apostolstwie świeckich Soboru Watykańskiego II. 
w Polsce, opartego na obecności i „pomocy danej w Jasnogórskim Obrazie", aktualne dla życia osobistego, wspólnotowego i społecznego cele. Po złożeniu Jasnogórskich Ślubów Narodu i przygotowaniu przez Wielką Nowennę (w latach 1957-1966) do jubileuszu Tysiąclecia Chrztu Polski wraz z Episkopatem oddał specjalnym aktem Polskę w niewolę Maryi za wolność Kościoła w świecie. Jan Paweł II doskonale rozumiał idee pomagania Kościołowi, dlatego jako papież potwierdza, że „istotą Aktu jest społeczne pragnienie niesienia pomocy Kościołowi Chrystusowemu zarówno w ojczyźnie, jak na całym globie ziemskim i to - przez Maryję. [...] Uważaj nas Polaków, jako naród, za całkowitą własność Twoją, za narzędzie w Twych dłoniach na rzecz Kościoła świętego [...] Czyń z nami, co chcesz [...], bylebyśmy z Tobą i przez Ciebie stawali się prawdziwą pomocą Kościoła Powszechnego" 35 .

Złożone śluby jasnogórskie czy akty oddania domagały się zarówno osobistej, jak i społecznej odpowiedzi. Dlatego w celu prowadzenia stałej maryjnej formacji w tym zakresie prymas Stefan Wyszyński powołał na Jasnej Górze 26 sierpnia 1969 roku dzieło i Ruch Pomocników Maryi Matki Kościoła. Tego dnia Prymas Tysiąclecia ogłosił również list, będący jednocześnie aktem inicjującym Ruch Pomocników Maryi. „Pragnę dziś otworzyć serce moje przed wami, aby odsłonić tajemnicę trwania Kościoła Chrystusowego w ojczyźnie naszej. Pragnę wam wyznać swoją wiarę $w$ to, że tę moc trwania zawdzięczamy obecnej w misterium Chrystusa i Kościoła Bogurodzicy. Pragnę was zaprosić do współdziałania - w duchu tej wiary i ufności - w dziele wprowadzania w życie naszych Ślubów Jasnogórskich i zobowiązań płynących z milenijnego Aktu oddania" ${ }^{36}$.

${ }^{35}$ List pasterski Prymasa Polski, Stefana kardynała Wyszyńskiego wzywająy ludzi dobrej woli do pomocy Kościołowi i chrześcijańskiej ojczyźnie przez Bogurodzicę Matkę Kościoła. Jasna Góra 26 VIII 1969 r., s. 48.

${ }^{36}$ Tamże, s. 36. 
Należy podkreślić, że ruch Pomocników powstał w czasie niezwykle trudnym dla Polski, kiedy Kościół był prześladowany przez komunistyczny reżim, a wszelkiego rodzaju grupy czy wspólnoty kościelne były celem cenzury i przedmiotem inwigilacji służb bezpieczeństwa. Prymas wierzył jednak, że kult Maryi jako Królowej Polski pomoże zrealizować idee soborowe, wprowadzając świeckich w dzieło misyjne Kościoła. Prowadził on do konkretnej troski o Kościół, czynnej miłości wobec drugiego człowieka i ojczyzny. Warto przytoczyć zwłaszcza najważniejsze elementy formacji eklezjalnej Pomocników: „Będę coraz głębiej poznawać Kościół, interesować się jego życiem i potrzebami; coraz goręcej Kościół miłować, słuchać Ojca Świętego, biskupów i kapłanów; służyć Kościołowi i pomagać mu modlitwą, ofiarą, cierpieniem i pracą. Odtąd przyznawać się będę otwarcie i odważnie do Chrystusowego Kościoła. Przynależność ta będzie mi największą radością i zaszczytem. Każde cierpienie Kościoła, każda jego udręka i prześladowanie są odtąd moim osobistym cierpieniem. Chcę wspierać Kościół w każdej potrzebie, brać żywy udział w troskach Ojca Świętego i biskupów polskich oraz moich duszpasterzy parafialnych. Będę ich wspierać przez moją modlitwę, czyn chrześcijański i apostolstwo" ${ }^{37}$.

Prymas Wyszyński w założeniach programowych tego maryjnego ruchu odwołał się do ewangelicznych źródeł jako inspiracji pomagania Kościołowi, a w nim żyjącemu w swoim ludzie - Chrystusowi. Wskazał na wzór Maryję, Jej osobę i dzieło, jako pierwszą Pomocnicę Boga. Ona przez swoje oddanie się Stwórcy do dyspozycji „pomogła Chrystusowi w dziele odkupienia - w Betlejem, w Nazaret, w Kanie Galilejskiej, na Kalwarii, w Wieczerniku Zielonych Świąt, stała się również najwspanialszą Pomocnicą odkupionej rodziny ludzkiej i każdego człowieka"38. Prymas zauważa aktualne wezwanie Maryi do włączenia się w dzieło pomagania. Pisze to w swym liście: „Czym są objawienia

37 Tamże, s. 50.

38 Tamże, s. 48. 
Matki Bożej w La Salette, Lourdes, Fatimie, Gietrzwałdzie, czy cicha służba na Jasnej Górze i w tylu sanktuariach? Tam, gdzie zagubiony człowiek oczekuje pomocy, gdzie wydaje się wszytko stracone - jest Pomoc i Ratunek - Maryja"39.

Aktualna sytuacja świata, a tym bardziej Kościoła w Polsce i Europie, wymaga wychowania do odpowiedzialności za Kościół Chrystusa i jego misję w świecie. Zapewne dokonuje się to na różne sposoby i przez rozliczne dzieła. Jednak „Niesienie pomocy jest zasadniczą i prawidłową postawą człowieka - mówił kard. Wyszyński do Pomocników. - Lepiej pomagać, niż oczekiwać pomocy. [...] Musimy więc - korzystając zresztą chętnie $z$ pomocy innych, wyrobić $w$ sobie postawę pomagania, niesienia pomocy, wrażliwości na potrzeby ludzi, własnego narodu i Kościoła. [...] Tylko taka postawa da nam w pełni szczęście, radość i właściwy rozwój naszego człowieczeństwa" ${ }^{\circ}$.

Kardynał nazywał siebie „Pomocnikiem Maryi”. Wiązał duże nadzieje z działalnością i rozwojem tego ruchu: „Gdyby w każdej parafii w Polsce powstała choćby maleńka wspólnota Pomocników Matki Kościoła, to nie boję się o dalsze losy Kościoła w Polsce" ${ }^{41}$. Chociaż dzieło zainicjowane przed pięćdziesięciu laty przez prymasa Stefana Wyszyńskiego wydało swoje owoce, to wciąż jest za mało grup czy wspólnot, które miałyby rzeczywiste odziaływanie na parafie czy na życie diecezji. Jubileusz Pomocników Matki Kościoła jest dobrym momentem na ożywienie tego charyzmatu w Kościele. Czyż nie najlepszym Pomocnikiem na czasy współczesne okazał się św. Jan Paweł II, który usłyszał to

39 Tamże.

40 Tamże, s. 47; por. J. Hadryś, Pomocnicy Matki Kościoła. Teoria i praktyka, Poznań 1999.

41 List pasterski Prymasa Polski, Stefana kardynała Wyszyńskiego wzywający ludzi dobrej woli do pomocy Kościołowi i chrześcijańskiej ojczyźnie przez Bogurodzicę Matkę Kościoła. Jasna Góra 26 VIII 1969 r., s. 50; por. Oddani Maryi w trosce o Kościół. Wybór przemówień Prymasa Tysiąclecia, red. A. Rastawicka, Warszawa 2019. 
wołanie prymasa z Jasnej Góry i przejął się potrzebą pomagania Maryi w Kościele?

\section{Zakończenie}

Historia Kościoła, a w nim dzieje obecności Maryi w Kościele i na ziemiach polskich przez ponad 1050 lat, wydają się dziełem ogromnym i bardzo dynamicznym. Duch Święty wciąż wzbudza nowe formy, będące wyrazem miłości Matki do dzieci, ale też miłości dzieci, które w swoim codziennym życiu odpowiadają na miłość swej Matki. Trudno w krótkim przedłożeniu opowiedzieć i wyczerpać zagadnienie inspiracji i działania Maryi Matki Kościoła w życiu Jej dzieci. Przedstawiłem tylko pewne akcenty, a może inspiracje do pogłębiania prawdy o Maryi, Matce Kościoła, przez tyle lat prowadzonej przez pasterzy Kościoła w Polsce, a szczególnie przez Prymasa Tysiąclecia. On, jak sam wyznał pod koniec swego życia, „zapalił duchową żagiew na Jasnej Górze” dla następnych pokoleń Polaków.

\section{Virgin Mary Mother of the Church. Inspirations for the Marian formation in the works of Primate Wyszynski and as based on the teachings of the Magisterium of the Church}

The article takes up the issue of the inspirations for the formation of the Christian maturity, as seen in the process of dedicating oneself to Her, Mother of the Church. The subject-matter of this issue is important for a number of reasons. First, during the Vatican II the Church took up praying and reflecting on its mission in the 20th century world. Thanks to this the Church rediscovered that Our Lady's presence - in the world so immersed in the crises 
- was a special grace and salvation for this world: Her presence as the Mother of the Lord's People in whom Christ lives.

On the one hand the Mother of God was worshipped from the beginning of Christianity, on the other hand, Primate Wyszynski and the shepards of the Church in Poland - referring to the history of Our Lady's cult and the program in the Polish Church - wished to bear witness that such salvation and hope for man and the world was only in total devotion to and the voluntary slavery of Mother of God's love. What is important, they did this by the Millenium Act at Jasna Gora in 1966; they did this on behalf of the nation for the freedom of the Church in the world.

Vows, promises, acts of devotion and dedication to the Mother of God pronounced especially at Jasna Gora to the Blessed Virgin Mary, Queen of Poland, have always been the expression of the Convenant with God through Her, the Mother of Her People as an intermediary. Jasna Gora chronicles and archives confirm this; the shepards of the Church (popes) and the pilgrims whose millions (over 4 ) continually visit the Sanctuary every year confirm this as well.

The Author, referring to the works of Primate Wyszynski and the teachings of the Magisterium of the Church, presents the inspirations for the Marian formation in four points. It is to be noted that the shepards of the church in Poland with the Primate as their leader - as it was stressed by Pope Paul VI and others - interpreted in an innovative way the implementing of the ideas concerning Our Lady and contained in the teachings of the Vatican II.

The aim of this article is to grasp at least a few of the Marian inspirations contained in the Marian program. Basic for the Marian formation is an individual dedication to Her, deepened by participating in the mystery of the life of Christ and Mary. The next stage is cooperation with Mary as the Mother in the community of the Church where Christ lives. The next two points emphasise the activity of Mary the Mother in the social 
life sphere whose concrete example is the movement "Supporters". The aim of this work and this movement is to support through prayer, testimony and committment - Christ who lives in His Church; to support through the cooperation with Mary the Mother of the Church as an example.

Heroic and even crazy project of the reneval and salvation of the world through the dedication and consecration to the Mother of the Church - as Pope John Paul II emphasised at Jasna Gora in 1979 - requires still more new people and responses. The Millenium Act gives us such hopes. 